\title{
Research on Integration of Telecom In- dustrial Value Chain in 3G Times
}

\author{
Yan Li, Min Fu, Xiaoqiang Hu \\ Jiangxi Science and Technology Normal University \\ Nanchang, China \\ Hanter3@163.com
}

\begin{abstract}
In the process of rapid development of the telecom industry, telecom industry value chain is constantly fission, extension and evolution. There are obviously evolution and change from communication service of $2 \mathrm{G}$ era of traditional voice lorded to information service of $3 \mathrm{G}$ era laying equal stress on voice and data. This paper analyses the development status of telecom industry value chain and points out the necessity of telecom industry value chain. From the telecom industry value chain integration strategy, the paper advances telecom industry value chain integration model in $3 \mathrm{G}$ times- Virtual integration. Telecom operator can improve their competitiveness and contribute to the harmonious and sustainable telecom industry developments.
\end{abstract}

Keywords: Telecom industry; 3G; Value chain

\section{Introduction}

In 1985, Harvard Business School professor Michael Porter in his book "competitive advantage" first proposed the theory of the value chain. Until now, with the coming of the $3 \mathrm{G}$ times, it is agreed that the future of telecom industry competition is the value chain's competition, the Unions' competition. The key to promote the development of data services is the telecom operators create a new business model which based on the industry value chain [1]. In a changing market environment, telecom operators must set up the belief of competition and cooperation. With other infrastructure operators, telecom operators cooperate in the bottom level of network, compete in the business level. What's more, through the integration of the value chain, telecom operators should take initiative to maintain system integrator, software developers, content providers and other links in industrial chain, establish an effective new model of business operations, create and get value together.

\section{Telecom Industry Value Chain}

\subsection{The basic concepts}

In the telecom industry, value chain focus on telecom operator, consisting of network device providers, content and service provider, system integrator, telecom operator, terminal equipment provider and the final clients and other elements. This is products as the object of value chain or value-added industrial value chain [2]. Every link in the chain are closely linked, interaction, produce greater synergetic effect than a single enterprise, change the way people access to information resources, make people feel the rapid development of telecom industry. 


\subsection{Telecom industry value chain members}

Now, telecom industry value chain has become a more complex, diversified and restraining each other and promoting each other huge industry value chain network[3] [4].

- The upstream of telecom industry value chain mainly includes: content / application providers (provide real-time content and instant messaging services), system integration providers, software providers (provide the telecom operation all kinds of software), network equipment providers (provide telecom network equipment) and traditional ISP.

- The middle of telecom industry value chain is Telecom operator, which in the key position of the telecom industry value chain. It is role of network access providers, part content integration company, are also a settlement platform, technology platform and marketing platform. By recombination, telecom operators include China Telecom, China Mobile and China Unicom three big operators.

- The downstream of telecom industry value chain mainly include terminal equipment providers and users

\subsection{The necessity of integrating tele- com industry value chain}

Each major telecom operators have built the industry value chain, but Compared with the foreign advanced operators, ours' still exist some problems such as coordination, management industry value chain and taking advantage of cohesion.

- Each existing links of telecom industry value chain lack of coordination and cooperation. With the telecom market improvement and development, the extension of the industry value chain continues ex- pand and the interior of the industry value chain tend to be complicated. The internal components promote and restrict each other at the same time. With any problems, it will affect the whole industry value chain's efficient operation [5].

- No form the relatively fair industry chain win-win situation profit pattern. In $3 \mathrm{G}$ times, if each links of new industry value chain can't organic combination, it can't flourish. The "binder" is interest. In telecom industry value chain interest is the most important and most concerned, that is the fee charged by the service divided into unfair. A DoCoMo company official once said: "maintain low fees are most favorable for content providers and mobile operators." By comparing with foreign excellent operators, operators existed many problems in charge mode. For example, in the charge term of mobile network, the content providers pay a sum "equalization fee" to operation, The purpose is to prevent sending the countless ads to mobile phone users, but the result is content providers are not only unprofitable, but also losses [6].

- The service contents lack creativity. Content providers want to achieve success and gain profit. The quality of the content is the key. In order to attract consumers, we must make content diversity and service targeted. At present, content providers based on short message services of popular business, lack of personalized service. Formed industrial scale of value-added services is also less. It will reduce consumers and prevent its development.

- Value-added business market competition mechanism remains to be further standardize and improve: At 
present, our telecom value-added business market competition state is in chaos. The serious problem is short message trap and encroach consumer rights and interests. If these problems are not well resolved, the value-added business will not remarkable advance.

$3 \mathrm{G}$ is certainly popular today. Our telecom operators should sized up the situation; grasp the overall development of the telecom industry direction. Through to the telecom industry value chain integration, activation, strengthen and redefine the relationship with other members, create and achieve value. In order to realize the telecom industry value chain effective interaction and comprehensive development, create the telecom industry in the prosperity.

\section{Telecom Industry Value Chain In- tegration}

To promote the healthy development of the $3 \mathrm{G}$ data services, our telecom operators must construct the close co-operation in value chain of the industry and make business model which everyone benefit from.

\subsection{Telecom operators positioned as a leader, others as collaborator}

The telecom operators must based on enterprise core capability, must carry out the industry chain strategic collaboration within and without, must consider respective advantages in the entire value creation, which as a basis to determine the role of other operators. First, Telecom operators should integrate resources effectively. Since any a new business launch, parties in the industry chain need accurately posit, work together, and give play to strong points.

\subsection{Telecom industry value chain in- tegration model- - virtual inte- gration}

Virtual integration is an advanced form of cooperation between enterprises. Its essence is the specialized production of individual enterprise through the cooperation way to achieve variety production or business. Under the traditional concept of enterprise, there are complete functions in enterprise operation, such as design, production, sales, and finance and so on. But under the idea of virtual integration, an enterprise can only reserve some of the key features, and other functions can virtualization. That is an enterprise refers to external power, such as upstream suppliers, downstream customer and competitors.

The telecom industry value chain integration model is showed in figure 1. Dotted line represents the virtual integration. Dash-dotted frame shows telecom operators select the key links of industrial chain according to its own condition (Not as shown all links in Figure). Telecom operators form virtual enterprise with other co-operative enterprises, product value and distribute value commonly.

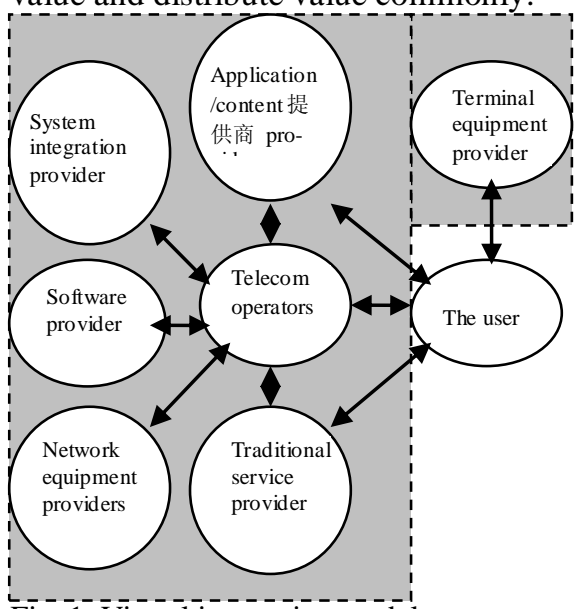

Fig. 1: Virtual integration model

Virtual integration can be divided into longitudinal virtual integration model and transverse virtual integration model. 
Longitudinal virtual integration model cooperate based on virtual upstream and downstream of industrial chain relationship. The main content is implementation of integrated telecom operator. Telecom operators and firms of industry chain between the upstream and downstream promote the whole industry development through their respective complementary resources. In longitudinal virtual integration model, telecom operators can choose partners from upstream and downstream. Downstream main contains system integration provider, software provider, network provider; upstream contains terminal equipment suppliers (including terminal equipment manufacturers and terminal equipment agents).

Transverse virtual integration model is a way of cooperation between telecom operators and other enterprises of different trades. It is mainly adapt to require- ments of two aspects development, which are the network integration and industrial convergence represented by e-commerce. (Telecom, cable TV and the Internet three nets fusion).In transverse virtual integration model, traditional service provider (including industry users, the complementary resources) and part of the competitors (other telecom operators) are selected by telecom operators.

\subsection{The Telecoms Industry Value Chain Integration Strategy}

The integration model of telecoms industry value chain - - the specific application of virtual integration are represented by terminal and financial support. In addition, there are alliances, resource sharing, and principal-agent variety forms of integration. As the below table I shows the specific conformity strategy.

TABLE I. The telecoms industry value chain integration strategy

\begin{tabular}{|c|c|c|c|}
\hline $\begin{array}{l}\text { Integration Ob- } \\
\text { ject }\end{array}$ & $\begin{array}{l}\text { Integra- } \\
\text { tion } \\
\text { Purpose }\end{array}$ & Integration Form & Integration way \\
\hline $\begin{array}{l}\text { Network } \\
\text { equipment } \\
\text { providers, } \\
\text { Software providers, } \\
\text { Systems integration } \\
\text { providers }\end{array}$ & $\begin{array}{l}\text { Developi } \\
\text { ng new } \\
\text { markets }\end{array}$ & $\begin{array}{l}\text { Alliance cooperation } \\
\text { ( } \mathrm{R} \& \mathrm{~d} \text { alliance } \\
\text { Price alliance) }\end{array}$ & $\begin{array}{l}\text { Cooperation in technical } \\
\text { training, } \\
\text { development, and network } \\
\text { equipment providers, } \\
\text { buyer's credit, etc }\end{array}$ \\
\hline $\begin{array}{l}\text { Content/application } \\
\text { providers }\end{array}$ & $\begin{array}{l}\text { Rich } \\
\text { content } \\
\text { services }\end{array}$ & $\begin{array}{l}\text { Alliance cooperation } \\
\text { ( R\&d alliance ) V } \\
\text { joint venture, } \\
\text { participation, } \\
\text { principal-agent, etc }\end{array}$ & $\begin{array}{l}\text { Build the Internet business } \\
\text { platform, you can choose } \\
\text { to enter. Constituting a } \\
\text { reasonable Internet use } \\
\text { charge and benefits } \\
\text { sharing model }\end{array}$ \\
\hline $\begin{array}{l}\text { Terminal } \\
\text { equipment } \\
\text { providers }\end{array}$ & $\begin{array}{l}\text { Welcome } \\
\text { the data } \\
\text { communi } \\
\text { cation } \\
\text { age }\end{array}$ & $\begin{array}{l}\text { Alliance cooperation } \\
\text { ( R\&d alliance 、 } \\
\text { Price alliance ) V } \\
\text { joint venture, } \\
\text { principal-agent, etc }\end{array}$ & $\begin{array}{l}\text { Subsidize terminal price, } \\
\text { Change the software } \\
\text { design terminal menu, and } \\
\text { even customize the } \\
\text { terminal }\end{array}$ \\
\hline $\begin{array}{l}\text { Other telecom } \\
\text { operators }\end{array}$ & $\begin{array}{l}\text { Realize } \\
\text { win-win }\end{array}$ & $\begin{array}{l}\text { Involving all models } \\
\text { of } \quad \text { cooperation } \\
\text { (alliances, resource }\end{array}$ & $\begin{array}{l}\text { Cooperation in new } \\
\text { business, such as malicious } \\
\text { consumer }\end{array}$ \\
\hline
\end{tabular}




\begin{tabular}{|l|l|l|l|}
\hline & & $\begin{array}{l}\text { sharing, joint } \\
\text { ventures, equity } \\
\text { participation, etc) }\end{array}$ & interconnection, etc \\
\hline $\begin{array}{l}\text { MAN, foreign } \\
\text { operators, } \\
\text { broadcasting and } \\
\text { other competitors }\end{array}$ & $\begin{array}{l}\text { Open the } \\
\text { market } \\
\text { quickly }\end{array}$ & $\begin{array}{l}\text { Joint ventures, } \\
\text { participation, capital } \\
\text { cooperation, leasing, } \\
\text { purchase, etc }\end{array}$ & $\begin{array}{l}\text { Cooperation in the } \\
\text { telecoms resources, } \\
\text { customer resources, and } \\
\text { channel resources }\end{array}$ \\
\hline $\begin{array}{l}\text { Traditional service } \\
\text { providers } \\
\text { (education, finance, } \\
\text { aviation and other } \\
\text { industries) }\end{array}$ & $\begin{array}{l}\text { Enhance } \\
\text { the } \\
\text { overall } \\
\text { competiti } \\
\text { ve power }\end{array}$ & $\begin{array}{l}\text { Union cooperation, } \\
\text { resource sharing, } \\
\text { joint vaunch targeted, practical } \\
\text { principal- venture, } \\
\text { agent participation, } \\
\text { etc }\end{array}$ & $\begin{array}{l}\text { Laund } \\
\text { telecom solutions; form } \\
\text { cross-industry alliance }\end{array}$ \\
\hline
\end{tabular}

\subsection{Telecom operators and partners on the basis of win-win coopera- tion}

Through innovation of the business operation pattern, Telecom operators and other segments of the telecom industry value chain won the different share economic interests, realize the win-win situation. But, not only reflected in the economic interest win-win, but also reflect in the following aspects. But, not only reflected in the economic interest win-win, but also reflect in the following aspects, such as shown in table II.

TABLE II. Telecom operators and partners on the basis of win-win cooperation

\begin{tabular}{|l|l|l|}
\hline Interests of Telecom 0perators & The Interests of Partners \\
\hline $\begin{array}{l}\text { Entering the enterprise } \\
\text { application market; Reduce data } \\
\text { center facilities, application and } \\
\text { storage server }\end{array}$ & $\begin{array}{l}\text { Application / } \\
\text { content } \\
\text { Provider }\end{array}$ & $\begin{array}{l}\text { Increased the sales channels } \\
\text { and sales, and to achieve scale } \\
\text { and scope economy (retail and } \\
\text { wholesale); } \\
\text { Joined forces, form a } \\
\text { differentiated competitive } \\
\text { advantage }\end{array}$ \\
\hline $\begin{array}{l}\text { Having the ability to provide } \\
\text { comprehensive, customized } \\
\text { solutions to the enterprise; } \\
\text { Obtain detailed knowledge of } \\
\text { application integration and } \\
\text { business needs }\end{array}$ & $\begin{array}{l}\text { Systems } \\
\text { integration } \\
\text { provider }\end{array}$ & $\begin{array}{l}\text { Improve the ability to carry out } \\
\text { an existing business; } \\
\text { Full use of existing skills } \\
\text { (economies of scope) }\end{array}$ \\
$\begin{array}{l}\text { Having the ability to provide a } \\
\text { wide range of different types of } \\
\text { new business and service }\end{array}$ & $\begin{array}{l}\text { Software } \\
\text { network } \\
\text { equipment } \\
\text { providers }\end{array}$ & $\begin{array}{l}\text { Business model switch from } \\
\text { "one-time sale" products model } \\
\text { to "according to the number of } \\
\text { charges(obtain a continuous } \\
\text { income)"products model }\end{array}$ \\
\hline $\begin{array}{l}\text { Provide new business and } \\
\text { services through customized } \\
\text { terminal }\end{array}$ & $\begin{array}{l}\text { Terminal } \\
\text { equipment }\end{array}$ & $\begin{array}{l}\text { Improve the development } \\
\text { level strengthen the position of } \\
\text { the industry chain }\end{array}$ \\
\hline $\begin{array}{l}\text { Broaden the sources of income } \\
\text { Expand marketing channels, } \\
\text { improve marketing efficiency }\end{array}$ \\
\hline
\end{tabular}


In addition, end-user and the entire national economy will benefit. End-user will enjoy the multi-level sub-domains, differentiation, and personalized service; the entire national economy will achieve scale and scope economies. So, the entire national economy will raise the rate of production and realize the benign development.

\section{Conclusion}

The telecoms industry value chain integration adapt to the development of $3 \mathrm{G}$ times telecoms industry chain. Demand for market, integrate resources, and create "win-win" industry value chain. The most characteristics of telecoms industry value chain integration are cooperation and win-win. The main rules as follows. Telecoms operators as the leading sector of telecoms industry chain integration. Other sectors in the telecoms industry chain is positioned as partners. Telecoms operators can take virtual integration mode (include vertical virtual integration model and transverse virtual integration model) to integrate industrial chain. The innovation of main source income is to develop more value added business. The innovation of the income distribution mainly lies in the redesign of the proportion of the income and objects of income. The key of telecoms industry value chain integration is innovation of telecoms operator's model

\section{References}

[1] Fransman M, Evolution of the telecoms industry into the internet age, Communications and Srrategies [M].Boston: Harvard Business School Press, 2010. 57-113.

[2] Liu Liang, Xiong Eeihua. China Telecom Industry Chain Structure Evolution [J]. Communications Management and Technology, 2007, (05).

[3] Zhu Xiaoyin. A Study on China Telecoms Operators Value Chain Change in the New Situation[J].Modern Business, 2009,(04).

[4] Rui Mingjie, Liu Mingyu.A Literature Review about Integration of Industry Chain $[\mathrm{J}]$. Industrial Economics Research, 2010, (06).

[5] Mei Jun. Based on the Value Chain Model of the Telecom Operation Research [J]. Communications World, 2009, (10).

[6] China Internet Network Information Center CNNIC. The 28 times China Internet network development state statistic report [EB/R] .[2011-0719].http://www.cnnic.net.cn. 